DOI: https://doi.org/10.31933/dijms.v2i3

Received: 24 November 2020, Revised: 22 December 2020, Publish: 23 January 2021

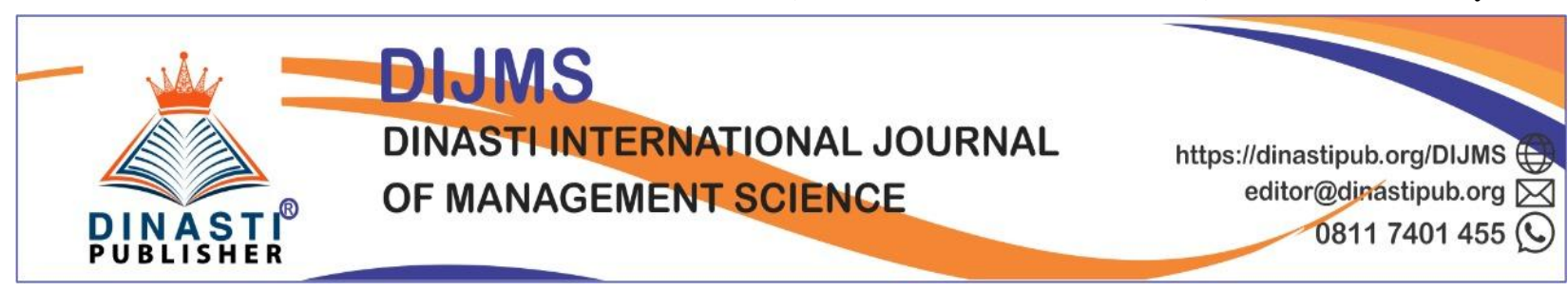

\title{
INVENTORY MANAGEMENT ANALYSIS BY OPTIMIZING THE FORCASTING METHODS (CASE STUDY AT PT XYZ INDONESIA)
}

\author{
Rosalendro Eddy Nugroho ${ }^{1}$, Maryana Resodiharjo ${ }^{2}$ \\ ${ }^{1)}$ Business Management Post Graduate, Mercu Buana University, Jakarta, rosalendro.eddy@ mercubuana.ac.id \\ ${ }^{2)}$ Mercu Buana University, Jakarta, maryono.resodiharjo@gmail.com
}

\section{Coresponding Author: Maryana Resodiharjo}

Abstract: This research aims to analyze inventory management by optimizing the forecasting method at PT XYZ Indonesia. The research approach that used was descriptive research with the aim of explaining and describing the object of research by qualitative and quantitative data. Qualitative data defined a description from the activities of a company which was carried out by managing inventory. Quantitative data in form of sales data, inventory data, quantity data of the arrival of goods in the company. The research was conducted in the Storage System department using data for 30 months from January 2014 to June 2016. From the ABC analysis data conducted by the company, A category was taken as many as 10 items (stock keeping units). The results of research using the three types of forecasting methods, it is known that on the article level the smallest MAD value was for D product with linear regression forecasting method. The smallest MAPE value was for C product with simple moving average forecasting method. On the level of aggregate products, the smallest MAD and MAPE values were exponential smoothing forecasting, thus the exponential smoothing forecasting method is a method to predicts the smallest and most accurate aggregate for product deviation.

Keywords: Inventory, simple moving average forecasting, exponential smoothing forecasting, linear regression forecasting.

\section{INTRODUCTION}

Effective inventory management is the key to success in any business, both in manufacturing and service companies. Inventory management will be unique and dynamic based on the strategies, business processes and values of each company (Willems, 2011). The effectiveness of inventory management will be the company's competitiveness to be able to develop in the long term.

PT XYZ Indonesia is a service company, which holds the XYZ brands and distributor. In 2014, They received top brand award from Frontier. PT XYZ applies information technology while running its business, namely by implementing an Enterprise Resource Planning (ERP) system. The implementation of information technology and especially inventory management at PT XYZ has become a reference for similar companies in the equipment and tools industry. 
In the business process, $\mathrm{XYZ}$ products were held through direct orders to manufacturers with the Original Equipment Manufacturer (OEM) system, products purchased from the factory were resold using the XYZ brand. Most of the products are imported products, received, forwarded and stored in the warehouse for distribution to all sales channels owned.

The sales hubs which are run consist of, direct sales to customers (direct sales), through its own store network (XYZ Tool Shop (TPK)), whole sales, either to companies in the group or to other dealers, sales hubs to modern retail and sales via electronic networks (e-commerce).

Although inventory management at PT XYZ has been carried out by applying those professional management methods and applying information technology, the inventory output is still far from the target set by the company. This could be seen from the stock value compared to the amount of the average sales value in months (month of sales (MOS).

Table 1. PT XYZ Month of Sale (MOS) Value for 2014-2016

\begin{tabular}{|c|c|c|c|c|c|}
\hline ABC Category & $\begin{array}{c}\text { Sales } \\
\text { Contribution } \\
(\%) \\
\end{array}$ & $\begin{array}{c}\text { MOS Target } \\
\text { (Bulan) }\end{array}$ & $\begin{array}{c}\text { MOS Actual } \\
2014 \\
\text { (Bulan) } \\
\end{array}$ & $\begin{array}{c}\text { MOS Actual } \\
2015 \\
\text { (Bulan) } \\
\end{array}$ & $\begin{array}{c}\text { MOS Actual } \\
2016 \\
\text { (Bulan) }\end{array}$ \\
\hline A & 80 & 4 & 4 & 5 & 5 \\
\hline B & 15 & 8 & 9 & 9 & 11 \\
\hline $\mathrm{C}$ & 5 & 12 & 20 & 23 & 27 \\
\hline Grand Total & 100 & 5 & 6 & 7 & 8 \\
\hline
\end{tabular}

Source: Internal Report, Inventory Management, June 2016

In terms of stock availability, this inventory management is still not optimal and below the target set. In aggregate stock availability targeted was $90 \%$, but from the evaluation its still below the standard, as it shown in Figure 1 below.

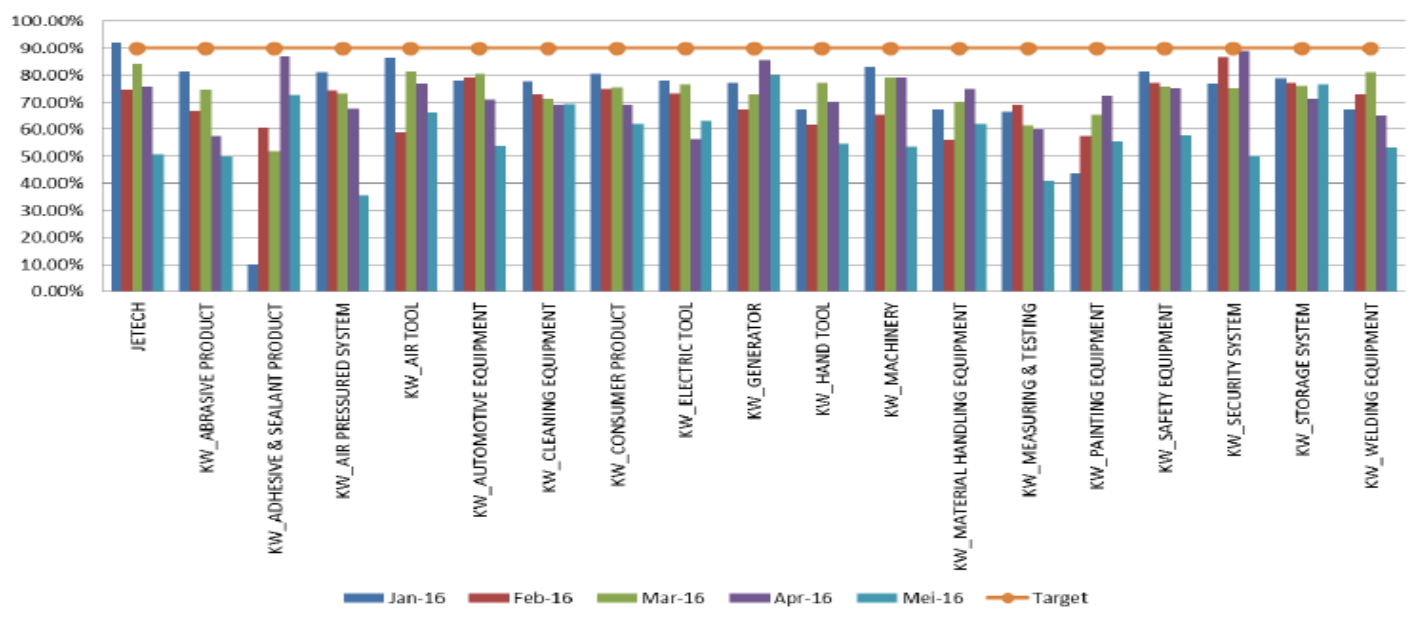

Source: Management Review, June 2016

Figure 1. Stock availability (fill rate) of PT XYZ during period January - May 2016

The aggregate average stock availability was around $70 \%$, but varies significantly by department. Beside that, the ease of internet access and technology, the existence of substituted goods makes the demand for XYZ products were uncertain, also it was greatly influenced by market changes which very fluctuating and the product life has getting shorter so there is an 
increase in items that are not sold, there has a tendency to decline in items in categories $\mathrm{A}, \mathrm{B}$ and $\mathrm{C}$ as it shown in Table 2 below.

Table 2. The Total of PT XYZ Stock Keeping Units (SKUs) in 2014 - 2016

\begin{tabular}{ccccc}
\hline ABC Category & $\begin{array}{c}\text { Sales } \\
\text { Contribution } \\
(\%)\end{array}$ & $\begin{array}{c}\text { SKU 2014 } \\
(\text { Pcs })\end{array}$ & $\begin{array}{c}\text { SKU 2015 } \\
(\text { Pcs })\end{array}$ & $\begin{array}{c}\text { SKU 2016 } \\
(\text { Pcs })\end{array}$ \\
\hline A & 80 & 743 & 698 & 680 \\
B & 15 & 1,350 & 1,142 & 1,091 \\
C & 5 & 6,098 & 6,530 & 6,056 \\
NS (No Sale) & & 5,960 & 6,210 & 6,246 \\
Grand Total & 100 & 14,151 & 14,580 & 14,073 \\
\hline
\end{tabular}

Source: Inventory Management, June 2016

To solve this problem, it is necessary to communicate with customers so the company will continue to grow. However, based on the survey's results conducted by customer service team, there has been a change in customer demand for XYZ products. Customers want products which are more fanciful to meet household needs, more lifestyle for daily needs.

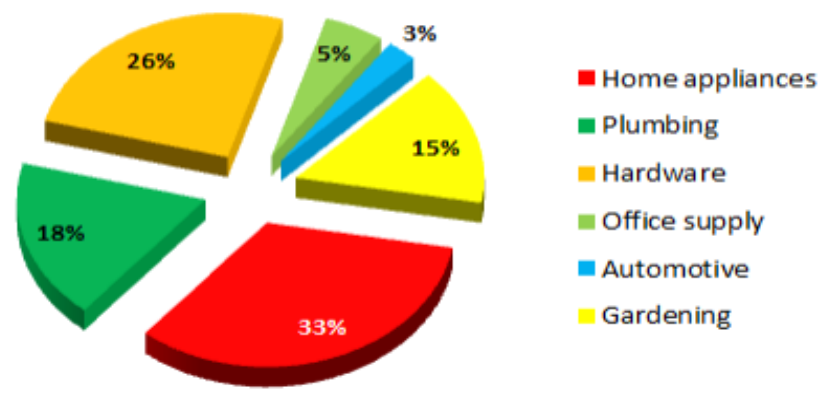

Source: Management Review, January 2016

Figure 2. Additional Product Range which Customers Want

Customer demand has changed because of products which have been too old, both in models and specifications. On the other hand, customers need the addition of new products to be provided by the company. There is a trend of changing customer demand. Thus, the accuracy of forecasting the size of market demand determines the amount of supply that should be stocked. On this basis, the authors wish to further analyze inventory management by optimizing the forecasting method at PT XYZ Indonesia.

\section{LITERATURE REVIEW Stock}

According to Piasecki (2009), inventory is goods that could be measured or tracked, goods that are managed, purchased, sold, stored, consumed, and produced. It is further explained that inventory could be in form of raw materials, work in process, finished good, or in form of supporting materials for other production processes, maintenance supplies, repair and operation.

\section{ABC Analysis}

Mulller (2011) explained that ABC analysis is used to classify or stratifying inventories. Group A describes the most popular product, the fastest selling product, the most important category, group B is the group after selling the fastest and group $\mathrm{C}$ is the slow selling category. 
Krajcovic and Plinta (2012) used the ABC analysis as part of developing comprehensive inventory control, classifying sales and inventory values into, A very important category, B fairly important and C less important

\section{Safety Stock}

A safety stock is needed to anticipate an increasing demand, an unstable product supply will hinder the delivery process (Mekel, C. et. al., 2013). Martono (2015) added that to ensure the process done continuously the safety stock is needed because of the variation in lead time.

\section{Demand Forecasting}

Further activities in inventory management will relate to forecasting, calculating safety stock, determining how much to make or buy (lot sizing), purchasing or replenishing (ordering / replenishment) and controlling all transactions (transactional control) accurately and immediately (Piasecki, 2009). Based on Arwani (2011), to be able to manage the inventory effectively, it is necessary to understand the control map for highly effective inventory through the stages of understanding, forecasting, and evaluation.

\section{Simple Moving Average Forecasting Methods}

Piasecki (2009) stated that the simple moving average forecasting assumption as if the future demand does similiar with previous demand. The greater the number of forecast data periods, the greater the fluctuation in demand.

\section{Exponential Smoothing Forecasting Methods}

Forecasters with this exponential smoothing method are most often used and inseparable mostly from all computerized forecasting programs (Jacobs and Chase, 2016). The exponential smoothing method used to accommodate the opinion if these current events are better on indicating the future.

\section{Linear Regression Forecasting Methods}

Linear regression is used both for forecasting time series and predicting causal relationships (Jacobs and Chase, 2016). It is further said that linear regression used for longterm forecasting of major events or aggregate planning. Although from the article level the demand may vary widely, as the demand for the aggregate level is smoother.

\section{Measurement Error/Forecasting Validation}

According to Piasecki (2009) Those estimation forecast errors have done to get the best forecasting methods. The estimation method of the forecasting accuracy level which is used in this research was Mean Absolute Deviation (MAD) and Mean Absolute Percent Error (MAPE).

\section{RESEARCH METHODS}

The research approach used descriptive research with the aim of explaining and describing the object of research by qualitative and quantitative data. Qualitative data explained a description of the activities that company carries out in managing inventory. Quantitative data in form of sales data, inventory data, quantity data of the arrival of goods in the company. 
This research has purposed to provide a clear picture of the inventory management carried out, the activities carried out by the company are recorded and evaluated.

The research which was conducted at PT XYZ, especially the Storage System department, uses data for 30 months from January 2014 to June 2016. From the ABC analysis data which conducted by the company, A category was taken as many as 10 items (stock keeping units), where the product was always included in the A category consecutively during period 2014 to 2016. A Category products studied with consideration from these category products are products which are important, make a large contribution and require the most attention (Mulller, 2011).

Data were grouped into qualitative and quantitative data categories, that obtained by observing, recording and documenting. The qualitative data of this research is in the form of notes, the results of meeting minutes, reports and results of internal meetings between divisions in the company, while quantitative data is obtained from company data in the form of Management Review (MR) data, monthly sales data, quantity data of arrival of goods and data collected which relevant from 2014 to 2016.

Research begins with the process of seeing, recording and reviewing the inventory management process which carried out by the company. In summary, the research process is carried out by following the research flow as in Figure 3 below.

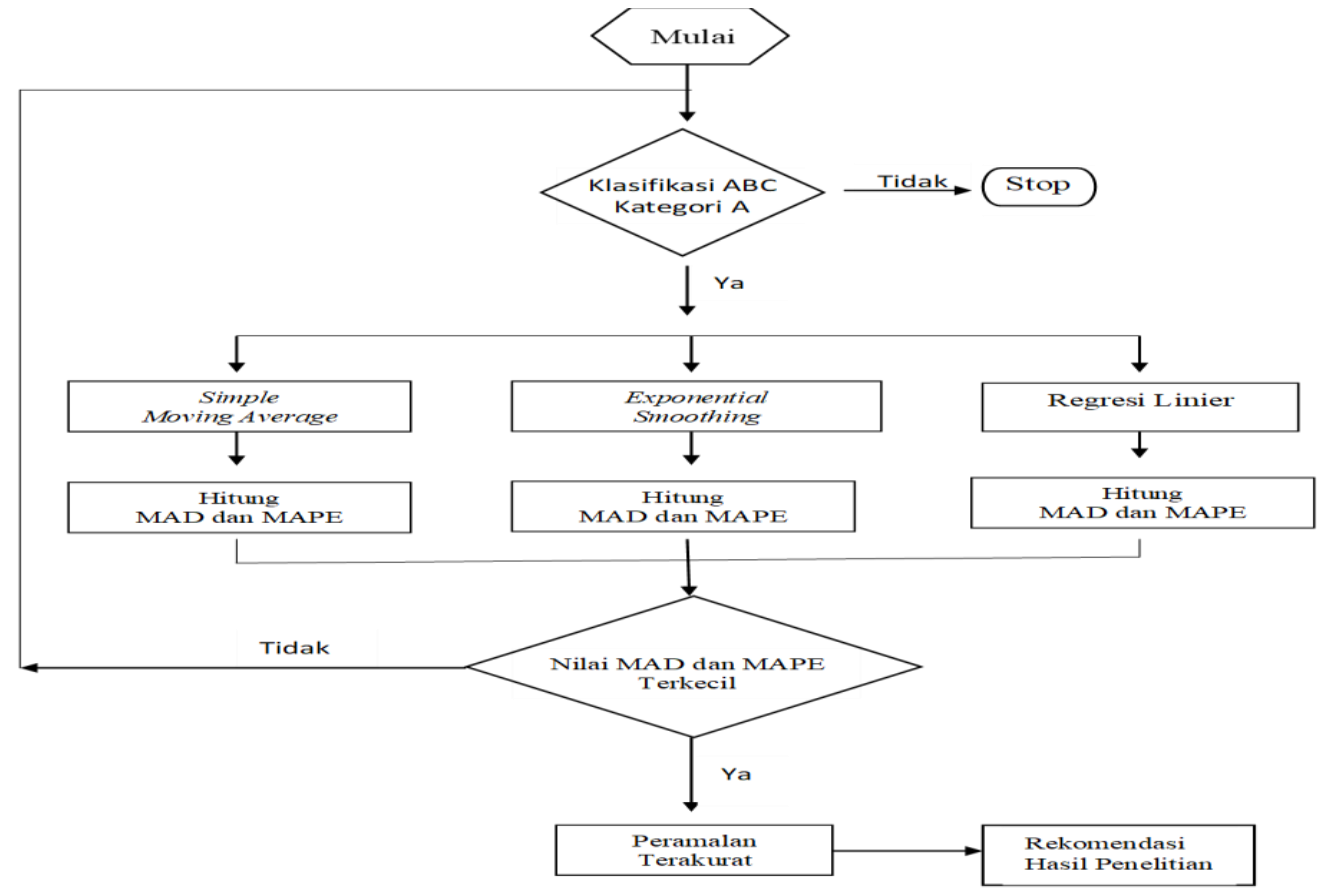

Figure 3. Research Flow

\section{RESULTS AND DISCUSSION \\ Simple Moving Average Forecasting}

Estimation of simple moving average forecast value was done by adding and searching for the average from 12 months and 24 months of data. Forecast value is obtained by removing the oldest value and adding the newest one into forecast that needs for next month. The MAD value of the 12 month average forecast ranged from the smallest 15.8 to 61.2 being the largest 
value. In the 24-month average forecast, the smallest MAD value was 12.2 and the largest MAD value was 50.2. Thus, forecasting with an average period of 24 months has a smaller or more accurate than MAD value. The MAPE value for the 12 month average forecast ranges from the smallest $22.44 \%$ to $54.34 \%$ which is the largest value. In the 24-month average forecast, the smallest MAPE value was $14.56 \%$ and the largest MAPE value was $56.29 \%$. Thus, forecasting with an average period of 24 months has smaller or more accurate MAPE value.

Table 3. MAD and MAPE values for Simple Moving Average Forecasting

\begin{tabular}{|c|c|c|c|c|c|}
\hline \multirow[b]{2}{*}{ No. } & \multirow{2}{*}{ Produk } & \multicolumn{2}{|c|}{ MAD } & \multicolumn{2}{|c|}{ MAPE } \\
\hline & & $12 \mathrm{bln}$ & 24 bln & 12 bln & 24 bln \\
\hline 1 & Produk A & 17.1 & 13.7 & $29.69 \%$ & $24.84 \%$ \\
\hline 2 & Produk B & 27.1 & 20.0 & $32.82 \%$ & $28.73 \%$ \\
\hline 3 & Produk C & 21.1 & 12.6 & $22.44 \%$ & $14.56 \%$ \\
\hline 4 & Produk D & 15.8 & 12.2 & $30.10 \%$ & $23.68 \%$ \\
\hline 5 & Produk E & 35.9 & 23.2 & $38.40 \%$ & $27.84 \%$ \\
\hline 6 & Produk F & 49.6 & 50.2 & $43.09 \%$ & $49.68 \%$ \\
\hline 7 & Produk G & 53.9 & 28.7 & $37.25 \%$ & $18.01 \%$ \\
\hline 8 & Produk $\mathrm{H}$ & 50.4 & 43.1 & $44.95 \%$ & $56.29 \%$ \\
\hline 9 & Produk I & 61.2 & 44.2 & $54.34 \%$ & $44.68 \%$ \\
\hline 10 & Produk $\mathbf{J}$ & 41.2 & 31.3 & $52.52 \%$ & $35.91 \%$ \\
\hline 11 & Produk Agregat & 185.0 & 149.7 & $19.62 \%$ & $17.22 \%$ \\
\hline
\end{tabular}

Forecasting value for Aggregate product demand with an average of 24 months of data as well as for products at the article level is generally smoother. MAD value of the aggregate product forecasting results with an average of 12 months of data and an average of 24 months of data was 185.0 and 149.7. MAPE value of demand for aggregate product forecasting was $19.62 \%$ and $17.22 \%$. Thus, the MAD and MAPE values for forecasting Aggregate products with an average of 24 months of data were smaller or has lower deviations which more accurate. Forecasting value with the number of data periods 24 months as a whole gives an idea that the more number of data periods used, the smoother demand forecasting results will have better accuracy (Jacobs and Chase, 2016).

\section{Exponential Smoothing Forecasting}

To see the value from the latest data on the forecast value description, the demand forecast value was calculated with different alpha $(\alpha)$ smoothing value, namely $\alpha=0.50$ and $\alpha$ $=0.90$. The results of MAD and MAPE calculations using the exponential smoothing forecasting method with different alpha $(\alpha)$ smoothing values. MAD value ranges from the smallest value of 12.2 for forecasting with $\alpha=0.08$ to the largest value of 50.8 , for forecasting with $\alpha=0.90$. While the MAPE value ranges from the smallest of $14.83 \%$ for forecasting with $\alpha=0.08$ to the greatest value of $58.24 \%$, for forecasting with $\alpha=0.90$. 
Table 4. MAD and MAPE values for Exponential Smoothing Forecasting Methods

\begin{tabular}{cccccccc}
\hline & Produk & \multicolumn{3}{c}{ MAD } & \multicolumn{3}{c}{ MAPE } \\
\cline { 3 - 7 } No. & & $\alpha=0,08$ & $\alpha=0,50$ & $\alpha=0,90$ & $\alpha=0,08$ & $\alpha=0,50$ & $\alpha=0,90$ \\
\hline 1 & Produk A & 13.5 & 15.6 & 16.2 & $24.42 \%$ & $28.23 \%$ & $29.46 \%$ \\
2 & Produk B & 19.4 & 20.0 & 23.5 & $27.89 \%$ & $28.67 \%$ & $33.74 \%$ \\
3 & Produk C & 12.9 & 13.8 & 15.2 & $14.83 \%$ & $15.91 \%$ & $17.56 \%$ \\
4 & Produk D & 12.2 & 13.3 & 14.6 & $23.68 \%$ & $25.68 \%$ & $28.17 \%$ \\
5 & Produk E & 21.4 & 18.2 & 23.3 & $25.72 \%$ & $21.92 \%$ & $27.96 \%$ \\
6 & Produk F & 45.8 & 34.4 & 33.6 & $45.37 \%$ & $34.06 \%$ & $33.31 \%$ \\
7 & Produk G & 30.3 & 37.0 & 42.0 & $18.99 \%$ & $23.23 \%$ & $26.38 \%$ \\
8 & Produk H & 39.2 & 37.3 & 44.5 & $51.28 \%$ & $48.73 \%$ & $58.21 \%$ \\
9 & Produk I & 40.2 & 27.6 & 25.0 & $40.72 \%$ & $27.91 \%$ & $25.29 \%$ \\
10 & Produk J & 35.0 & 46.2 & 50.8 & $40.14 \%$ & $52.99 \%$ & $58.24 \%$ \\
11 & Produk Agregat & 138.2 & 72.8 & 54.1 & $15.90 \%$ & $8.38 \%$ & $6.23 \%$ \\
\hline
\end{tabular}

From the article level that seen from MAD value for D product which has the smallest value, namely 12.2 , and the next MAD value is 12.9 for $\mathrm{C}$ product, both of occured in exponential smoothing forecasting method with $\alpha=0.08$. When viewed from the MAPE value, the smallest was for $\mathrm{C}$ product, which is $15.91 \%$ with exponential smoothing forecasting with $\alpha$ $=0.50$. On the aggregate level (Aggregate products), forecasting with the smallest or most accurate MAD and MAPE value is 54.1 and $6.23 \%$ by exponential smoothing forecasting with $\alpha=0.90$. Thus, the forecasting research from aggregate level exponential smoothing method confirmed that the general assumption which forecasted by the latest data $(\alpha=0.90)$ was extra accurate from the MAPE value on aggregate level, exponential smoothing forecasting was more accurated than using the article level (Jacobs and Chase, 2016) and (Meindl and Chopra, 2016).

\section{Linear Regression Forecasting}

The data period used as the basis for forecasting the regression is the monthly demand data for 24 months. Forecasting by linear regression method was carried out for the forecast horizon for the next 6 months. On the article level, the MAD scores ranged from the smallest value of 10.2 to the largest at 55.7. The smallest MAPE value was $17.99 \%$ and the largest was $63.86 \%$.

Table 5. MAD and MAPE values from the Linear Regression Forecasting Methods

\begin{tabular}{cccc}
\hline No. & Produk & MAD & MAPE \\
\hline 1 & Produk A & 26.8 & $48.64 \%$ \\
2 & Produk B & 33.3 & $47.85 \%$ \\
3 & Produk C & 17.0 & $19.58 \%$ \\
4 & Produk D & 10.2 & $19.68 \%$ \\
5 & Produk E & 26.7 & $32.06 \%$ \\
6 & Produk F & 26.0 & $25.74 \%$ \\
7 & Produk G & 28.7 & $17.99 \%$ \\
8 & Produk H & 32.0 & $41.83 \%$ \\
9 & Produk I & 34.7 & $35.08 \%$ \\
10 & Produk J & 55.7 & $63.86 \%$ \\
11 & Produk Agregat & 118.7 & $13.65 \%$ \\
\hline
\end{tabular}

Seeing from that MAPE value, based on the Aggregate product regression forecasting aggregately is the most accurate compared to the regression forecasting on article level. Thus if 
this forecasting research confirmed that the general assumption of forecasting which is more accurate than the article level (Jacobs and Chase, 2016) and (Meindl and Chopra, 2016).

\section{Forecasting Validation}

From the article level, the smallest MAD value was 10.2 for D product with linear regression forecasting method, thus it is more accurate. The smallest MAPE value was $14.56 \%$ for $\mathrm{C}$ product with the simple moving average forecasting method $\mathrm{n}=24$ months.

Based on the aggregate product level, the smallest MAD value was 54.1 and the smallest MAPE value was $6.23 \%$ by the exponential smoothing forecasting method with $\alpha=0.90$. The exponential smoothing forecasting method with $\alpha=0.90$ was the method to predicted the smallest and most accurate aggregate product deviation.

Table 6. MAD and MAPE Value Forecasting Methods of Simple Moving Average, Exponential Smoothing and Linear Regression $\mathbf{n}=24$ Months

\begin{tabular}{cccccccccccc}
\hline \multirow{2}{*}{ No. } & \multirow{2}{*}{ Produk } & \multicolumn{1}{c}{ MAD } & \multicolumn{5}{c}{ MAPE } \\
\cline { 2 - 11 } & & MA24 bln $\alpha=0,08$ & $\alpha=0,50$ & $\alpha=0,90$ & R 24 bln & MA 24 blr $\alpha=0,08$ & $\alpha=0,50$ & $\alpha=0,90$ & R 24 bln \\
\hline 1 & Produk A & 13.7 & 13.5 & 15.6 & 16.2 & 26.8 & $24.84 \%$ & $24.42 \%$ & $28.23 \%$ & $29.46 \%$ & $48.64 \%$ \\
2 & Produk B & 20.0 & 19.4 & 20.0 & 23.5 & 33.3 & $28.73 \%$ & $27.89 \%$ & $28.67 \%$ & $33.74 \%$ & $47.85 \%$ \\
3 & Produk C & 12.6 & 12.9 & 13.8 & 15.2 & 17.0 & $14.56 \%$ & $14.83 \%$ & $15.91 \%$ & $17.56 \%$ & $19.58 \%$ \\
4 & Produk D & 12.2 & 12.2 & 13.3 & 14.6 & 10.2 & $23.68 \%$ & $23.68 \%$ & $25.68 \%$ & $28.17 \%$ & $19.68 \%$ \\
5 & Produk E & 23.2 & 21.4 & 18.2 & 23.3 & 26.7 & $27.84 \%$ & $25.72 \%$ & $21.92 \%$ & $27.96 \%$ & $32.06 \%$ \\
6 & Produk F & 50.2 & 45.8 & 34.4 & 33.6 & 26.0 & $49.68 \%$ & $45.37 \%$ & $34.06 \%$ & $33.31 \%$ & $25.74 \%$ \\
7 & Produk G & 28.7 & 30.3 & 37.0 & 42.0 & 28.7 & $18.01 \%$ & $18.99 \%$ & $23.23 \%$ & $26.38 \%$ & $17.99 \%$ \\
8 & Produk H & 43.1 & 39.2 & 37.3 & 44.5 & 32.0 & $56.29 \%$ & $51.28 \%$ & $48.73 \%$ & $58.21 \%$ & $41.83 \%$ \\
9 & Produk I & 44.2 & 40.2 & 27.6 & 25.0 & 34.7 & $44.68 \%$ & $40.72 \%$ & $27.91 \%$ & $25.29 \%$ & $35.08 \%$ \\
10 & Produk J & 31.3 & 35.0 & 46.2 & 50.8 & 55.7 & $35.91 \%$ & $40.14 \%$ & $52.99 \%$ & $58.24 \%$ & $63.86 \%$ \\
11 & Produk Agregat & 149.7 & 138.2 & 72.8 & 54.1 & 118.7 & $17.22 \%$ & $15.90 \%$ & $8.38 \%$ & $6.23 \%$ & $13.65 \%$ \\
\hline
\end{tabular}

\section{Discussion}

The demand data used data on products from the same supplier, with the aim of minimizing the bias in order, production and delivery time. Overall, the use of this research data was also intended to have product characteristics which are not much different. The general understanding in the field of forecasting is that predicting products with the latest data with the aggregate level is more accurate than the article level, this is understood because on the aggregate level the fluctuation in demand will be smoother and it could be proven on this research (Piasecki, 2009) and (Meindl and Chopra, 2016).

The simple moving average forecasting methods from the MAD forecasting value in this research has the smallest value of 12.2 compared to research, Simatupang (2011) with an MAD of 260.04, Yanti, et al (2016) with an MAD of 3475.00, Prasetyo ( 2017) with an MAD of 1167, Heriansyah and Sarwani (2018) with an MAD of 5989, and Maricar (2019) with an MAD of 284. If seen from the MAPE value this research has accuracy around $85.44 \%$ with MAPE value of $14.56 \%$. This MAPE value was greater than Yanti, et al (2016) at 5.99\%, Prasetyo (2017) at 3.06\% but smaller than Heriansyah and Sarwani (2018) with a MAPE value of $26 \%$. Deviation of the forecast value and the accuracy of each product will vary and depend on the characteristics from each products. 
Forecasting exponential smoothing methods, Based on MAD forecasting value, this research has the smallest value which is 12.2 compared to research, Simatupang (2011) with MAD of 216.03, Yanti, et al (2016) with MAD of 3603.13, Hariansyah and Sarwani (2018) with an MAD of 6810 and Maricar (2019) with an MAD of 203. Seeing from the MAPE value, the forecasting from this research has an accuracy of $85.17 \%$ with an MAPE value of $14.83 \%$. This MAPE value was greater than the results of research by Yanti, et al (2016) with a MAPE of $6.28 \%$ but smaller than the results of Heriansyah and Sarwani (2018) research with MAPE of $33 \%$. It cannot be concluded which research results are the best because the value of the deviation and the accuracy of this forecast depends on the characteristics of each product and those many influencing factors.

The linear regression forecasting method, According to NAD forecasting value from this research has the smallest value of 10.2 and the smallest also when it compared to previous research. Kartika, et al (2014) has a MAD forecasting value of 18.58 and Iksan et al (2018) has the smallest MAD forecasting value of 11.07. When viewed from the MAPE value, the outcome from this research has a value of $17.99 \%$ greater than the results from Iksan, et al (2018) with a MAPE value of $2.05 \%$ but less accurate than the research from Iksan, et al (2018) which has an accuracy value of $97.95 \%$, while this research only has an accuracy of $82.01 \%$.

Forecasting product demand is exciting and always challenging. There is no magic algorithm in forecasting (Bower, 2013). Goods inventory management, including the demand forecasting process which is the management that fits with the company's strategy (Workman and Scheilder, 2009). Inventory management will be unique for each company because it greatly affects the value of the company (Willems, 2011).

\section{CONCLUSION AND SUGGESTION Conclusion}

Based on those results from the research above, it could be concluded that:

1) Forecasting by the simple moving average method, as the most accurate demand forecasting results obtained on the article level are for C and D Products. C Product has the smallest MAPE value, which is $14.56 \%$, while product $\mathrm{D}$ has the smallest MAD value, namely 12.2. Forecasting by the exponential smoothing method, on the article level, it could be seen from the MAD value, D product has the smallest value, namely 12.2 with $\alpha=0.08$. If it's seen from the MAPE value, the smallest value was for $\mathrm{C}$ product which is $15.91 \%$ with $\alpha=0.50$. By the aggregate level (Aggregate products), forecasting with the smallest or most accurate MAD and MAPE values was 54.1 and $6.23 \%$ which in exponential smoothing forecasting with $\alpha=0.90$. Forecasting by linear regression method, on the article level, the regression forecasting could be seen from the most accurate MAD value for D product of 10.2. Meanwhile, if its seen from the smallest or most accurate MAPE value was for G product, which is $17.99 \%$.

2) From those three types of forecasting methods, from the article level has the smallest MAD value was for $\mathrm{D}$ product with linear regression forecasting method. The smallest MAPE value was for $\mathrm{C}$ product with a simple moving average forecasting method. From the level of aggregate products, the smallest MAD and MAPE values are exponential smoothing forecasting, thus the exponential smoothing forecasting method is a method to predict the smallest and most accurate aggregate product deviation. 


\section{Suggestions}

Based on the above conclusions, the authors need to submit suggestions to the next researcher, such as:

1) Forecasting is very unique for each company, therefore forecasting needs to be done in detail for each company by utilizing all methods, assumptions and seeing the characteristics of each product. There is no magic algorithm in forecasting (Bower, 2013).

2) Further research is needed for sake of amount for savings or profit received by the company if it forecasts demand accurately.

1) There is no need to fear about mistakes when doing forecasting, because forecasting is a job which assumes that the value of forecasting is always wrong and difficult to do but it provides great benefits in managing inventories in particular (Paiseki, 2009).

\section{REFERENCES}

Arwani R, Ahmad. 2011. Highly Effective Inventory Management. PPM Manajemen. Jakarta.

Bower, Patrick. (2013). Forecasting New Product in Consumer Goods. Journal of Business Forecasting, Winter 2012-2013.

Chopra, Sunil dan Peter Meindl. (2016). Supply chain management. Strategy, Planning \& Operation. Sixth Edition. Pearson Education Limited. England.

Heriansyah, E. dan Sarwani Hasibuan. (2018). Implementasi Metode Peramalan Pada Permintaan Bracket Side Stand K59A. Jurnal PASTI Volume XII No.2.

Iksan, N., Yogi P. Putra dan Erika D. Udayanti. (2018). Regresi Linier Untuk Prediksi Permintaan Sparepart Sepeda Motor. Information Technology Engineering Journals Vol. 03(02).

Jacobs, F. Robert \& Richard B. Chase (2016). Manajemen Operasi dan Rantai Pasokan. Operations and Supply Chain Management. Edisi 14. Salemba Empat- McGraw-Hill Education. Jakarta.

Kartika, Luh G. S., Ratna K. W. dan Melati P. W. (2014). Komparasi Metode Multiple Regression dan Regresi Sederhana Untuk Peramalan Volume Penjualan. Eksplora Informatika Vol. 4(1).

Krajcovic, M., \& Plinta, D. (2012). Comprehensive approach to the inventory control system improvement. Management and Production Engineering Review,3(3), 34-44.

Maricar, M. Azmar. (2019). Analisa Perbandingan Nilai Akurasi Moving Average dan Exponential Smoothing untuk Sistem Peramalan Pendapatan pada Perusahaan XYZ. Jurnal Sistem dan Informatika Vol.13(2).

Martono, R. (2015). Manajemen Logistik Terintegrasi. PPM Manajemen, Jakarta.

Mekel, C., Samuel P.D. Anantadjaya, dan Laura Lahindah, (2014). Stock Out Analysis: An Empirical Study on Forecasting, Re-Order Point and Safety Stock Level at PT Combiphar, Indonesia. Review of Integrative Business \& Economics Research Vol 3(1)

Muller, Max. (2011). Essentials of Inventory Management. Second Edition. AMACOM American Management Association. USA. 
Piasecki, David J. (2009). Inventory Management Explained: A focus on Forecasting. Lot Sizing, Safety Stock, and Ordering Systems. OPS Publishing. USA.

Prasetyo, Danny. (2017). "Analisis Peramalan Penjualan Produk Tinplate pada PT Latinusa Tbk”. Tesis. Program Magister Manajemen. Program Pascasarjana. Universitas Mercu Buana. Jakarta.

Simatupang, Agustina. (2011). "Analisis Perencanaan dan Pengendalian Obat Dalam Daftar Obat Standar(DOS) di Instalasi Farmasi Rumah Sakit Ibu dan Anak Hermina Bekasi”. Tesis. Magister Administrasi Rumah Sakit, Universitas Indonesia. Depok.

Willems, S. P. (2011). How Inventory Optimization Opens Pathways to. Supply Chain Management Review.

Workman, J., \& Scheidler, N. (2009). Safety stock: Everybody wants to use, nobody wants to own. The Journal of Business Forecasting, 28(3), 4.

Yanti, Ni Putu. L. P., I.A. Mahatma Tuningrat, dan A.A.P. A. Suryana Wiranatha. (2016). Analisis Peramalan Penjualan Produk Kecap Pada Perusahaan Kecap Manalagi Denpasar Bali. Jurnal Rekayasa dan Manajemen Agroindustri, Volume 4 (1). 